\title{
A Critical Introduction to 12 Years a Slave
}
- Kathryn Hampshire, Bryce Longenberger, Ramona Simmons, and Esther Wolfe, Ball State University

$\mathbf{I}^{\mathrm{n}}$ 2013, director Steve McQueen released 12 Years a Slave, his film adaptation of Solomon Northup's 19th century slave narrative of the same name. However, in spite of overwhelming public response and widespread critical acclaim, currently the film has received very little attention within academia, and has yet to be made a significant subject of critical scholarship and discussion. In response, this collection addresses what the authors view as a critical lack of contextualization of the film within a larger body of theory and critical analysis.

Interpreting McQueen's film within analytic frameworks including comparative slavery studies, trauma studies, feminist theory, film theory, and the rhetoric of visual cultures, the authors create a wide range of analyses that address several critical questions. In the article "Violent Instability: Images of the Violence of Slavery in 12 Years a Slave and Visual Cultures," author Esther Wolfe examines the inherent ambiguity of McQueen's realist style, contextualizing this ambiguity within a larger critical discussion of the instability of images of slavery in visual culture and its relation to the paradox of bearing witness to atrocity. Deepening this conversation on images of the violence of slavery, author Kathryn Hampshire, in "On Cinematography and Discomfort in 12 Years a

\section{Abstract:}

In this critical anthology of essays, the authors examine Steve McQueen's 12 Years a Slave from a variety of analytic frameworks, including feminist theory, trauma studies, film theory, and deconstruction. The authors explore critical questions concerning the politics of representing trauma and violence, the politics of slave suicide, and the intersections of race and gender in the experiences of slave women.

\section{KEY WORDS:}

12 Years a Slave, Steve McQueen, slavery, violence, visual culture, cinematography, mistresses, suicide

\section{TABle of Contents}

"Violent Instability": Images of the Violence of Slavery in 12 Years a Slave and Visual Culture

Esther Wolfe

On Cinematography and Discomfort in 12 Years a Slave Kathryn Hampshire

Scoured Souls: The Imbalance between Mistresses and Female Slaves Ramona Simmons

The Inability to Commit Suicide: An Analysis of Steve McQueen's 12 Years a Slave

Bryce Longenberger 
Slave," analyzes McQueen's film in the context of its cinematography, examining the political power of discomfort brought about by the lingering cinematic gaze. The last two articles in this collection focus this discussion of violence further by unpacking specific dynamics of slave experiences. In "Scoured Souls: The Imbalance between Mistresses and Female Slaves," author Ramona Simmons interprets the film within the context of gender power and feminist analysis, examining the relative positions of female slave and plantation wife within interconnected systems of slavery and patriarchal oppressions. Finally, specifying this context of gender violence, in "The Inability of Committing Suicide: An Analysis of Steve McQueen's 12 Years a Slave," author Bryce Longenberger examines the nature of suicide within slave systems, exploring interpretations of suicide as resistance and degradation from the position of Patsey. In presenting this collection, the authors hope to break important analytic ground, contributing to the current body of critical work while opening up space for continued study. It is also the hope of the authors that analysis of McQueen's film will bring to bear the ways in which the issues raised in this collection continue to be present and relevant in our contemporary world-in the forms of modern slave systems and interconnected legacies of racist violence and oppression. 


\section{"Violent Instability": Images of the Violence of Slavery in 12 Years a Slave and Visual Culture -Esther Wolfe}

Of the critical conversations surrounding Steve McQueen's 12 Years a Slave, perhaps the most pervasive revolves around the film's realism, specifically its realistic portrayal of the violence and trauma of slavery and the image of the tortured slave body. Using his trademark realist cinematographic style, McQueen creates prolonged, unflinching images of slave torture and suffering, lingering on graphic scenes of brutality, including whipping, hanging, beatings, and rape. Realist cinematography, by attempting to replicate and recreate the real, can be seen as an attempt to create a pure representation of experience, to bypass instability and get outside interpretation. However, realist images also contain an imbedded ambiguity at the very site of their realism. In replicating and recreating the real, realist images are framed constantly by what they are not; they are defined continuously and simultaneously by what is not there and could not be represented. Realism, it would appear, cannot get around this fundamental split. In this way, by representing the real, by recreating experience in order to capture meaning, what is instead represented is the very politics of "seeing" itself.

The paradoxical ambiguity of realism has specific implications with regards to McQueen's realist images, and to the visual representation of slavery. What does it mean, then, to portray slavery "realistically," and how can we locate this representation? By confronting the viewer with the image of the tortured slave body, by attempting to recreate the violence and trauma of slavery, McQueen's images occupy a fundamental split. Framed constantly by what is not there, by what can never be represented, McQueen's images perform the politics of "seeing," the instability of representation, and the impossibility of recreating the historical trauma and lived experience of slavery.

This inherent ambiguity, the instability and impossibility of McQueen's images paradoxically imbedded at the very site of realism, is performed and in a sense "played out" by the critical response to the film. Response to the film's realist images of slave suffering and torture, of the violence and trauma of slavery, has elicited a competing discourse. Although the film's depiction of the violence and trauma of slavery has prompted widespread and important dialogue, individual critical conversations have been largely devoted to an implicit project of resolving these images, of framing and containing them by arguing for and against what they are believed to engage. As a result, little has been done to examine the politics and implications of this ambiguity itself, and what it might perform. In fact, in the very act of attempting to resolve the ambiguity of McQueen's images, this competing discourse strangely repeats and performs the very paradox of realism itself. By attempting to capture meaning and exclude other interpretations, these discourses must constantly frame and define themselves based on what is inherently not there, against the very ambiguity they mean to exclude. In this way, the discourse surrounding McQueen's realist images of the trauma and violence of slavery perform a fundamental split that continuously reflects and implicates the images themselves.

This analysis contextualizes the paradoxical instability of McQueen's realist images of the trauma and violence of slavery and the discourse that surrounds them within a larger lineage of the history and politics imbedded in the depiction of slavery within visual culture. Taking the 
ambiguity of McQueen's realist depiction as its own political site, where the audience is confronted simultaneously with the violence of slavery as well as with the inherent impossibility of its representation, this analysis probes the ways in which McQueen's realist images actively resist and exceed the historical frame, getting at fundamental questions of trauma and representation in relation to the violence and collective memory of slavery.

Much theoretical work has been devoted to the visual representation of the transatlantic slave trade, particularly to images of the tortured slave body. Several questions are of critical concern to theorists who study these representations, among them, how can we orient and understand depictions of slavery in visual culture? How do we "read" images of slavery? What implications do these readings have on whether the memory of slavery can ever be excavated and represented? These difficult questions have prompted a range of critical interpretations of images of slavery in visual culture, a discourse that is directly engaged by the critical response to McQueen's film.

In one framing of this discourse, scholars of comparative slavery and visual culture have argued that graphic depictions of slave torture and abuse challenge and interrogate persuasive, insidious histories of the romanticization of slavery via the production and consumption of images, particularly the image of the "happy slave" and the "good master." Part of the "Western myths devoted to the memory of slavery," these romanticized images are indicative of a profound inability within European and North American cultural consciousness to cope with the memory of slavery and its place within the national imaginary, instead subjecting it to further management and containment through appropriation and erasure. As a result, argues Natalie Zemon Davis, non-romanticized depictions of slavery in visual culture, particularly images of the suffering, tortured slave body, "can bring to life a person on the boundaries of historical possibility" (136). In this vein, graphic images of slavery can be read as an important form of resistance and counter-speech to violent modes of erasure through romanticized cultural and visual production.

This reading of images of the tortured slave body as resistant and confronting is echoed in Kendra James's review of McQueen's 12 Years a Slave, published in the online blog Racialicious. In her review, James argues that the film's depiction of violence, particularly its depictions of slave tortures such as rape, beatings, lynching and whipping, is "necessary" in order to confront the viewer with the reality of slavery; to facilitate a "looking at the truth of our own past.” According to James, the images of violence and slave torture in McQueen's 12 Years a Slave "do not assuage the viewer's sense of comfort. Bluntly, this was not made taking the sensibilities of a white American audience into consideration." In this way, by reading McQueen's images as a political departure from palatability that confronts viewers with the reality of slavery, James's review implicitly engages a larger discourse on images of slavery in visual culture, in which images of slave torture are interpreted as a form of political resistance to romanticization and erasure.

This critical framing is further expanded by scholars who work the intersections of trauma studies and image culture. Exploring the relationship between trauma and visual media, scholars have argued that the inherent nature of film itself creates a particularly effective medium for representing the individual, lived experience and transhistorical trauma of slavery. According to trauma studies scholars, film becomes an effective means of representation because the medium performs and mimics the metaphysical experience of trauma. According to Fryd, "video is an appropriate medium... for it easily conveys fragmentary images and narratives, fantasy, 
and unspeakable acts" (148). The inherent estrangement and strangeness of film as media, the dissociation between subject and image, its imbedded discontinuity and nonlinearity, embodies "the trauma victim's sense of disruption in lived experience and psychic coherence" (Fryd, 148). In this way, graphic images of slavery can be read as performing both the act of witnessing and the experience of trauma via the medium of film itself.

This interpretation is also echoed within James's Racialicious review of McQueen's 12 Years a Slave. In her review, James notes that the film's cinematographic aspects often collapse and displace linear temporality, mimicking the disorientation and discontinuity of the trauma of slave life. As James notes, at any point in the film "This could be 12 months, 12 weeks or 12 years and we wouldn't have known; I even lost track of how long I'd been in the theater." James goes on to say that, "There's no clear changing of the seasons; no transition from spring to summer to fall." Rather, "Time is marked by the passing of violence rather than the passing of the seasons, and it blurs and stretches and bunches together in places." Here, James directly engages a larger discourse on depictions of slavery, in which the medium of film itself mimics the trauma of slavery, its confusion and dissociation.

These particular framings of the relationship between slavery and visual culture have also been strongly challenged within contemporary discourse. In Slavery, Empathy, and Pornography, Marcus Wood argues that the rhetorical framing of images of slave punishment and suffering reveals a pornographic impulse bound up in the act of sympathetic viewing. According to Wood, sympathetic images of slave torture and abuse "treat the slave body... as punishment object or fetish in directly exploitative and eroticized ways which are blatantly pornographic" (93). In these images, argues Wood, the slave body is rhetorically commodified and objectified for sympathetic consumption by a voyeuristic white audience. In viewing these images of slave punishment, the white audience is invited to "fantasize his/her own fictions of torture" (93), to imagine themselves in both the position of torturer and tortured. In this way, the image of the punished slave body is rhetorically commodifed as fetish object for the erotic pleasure of sympathetic white fantasy. According to Wood, this "auto-erotics of sympathy" incorporates both a possessive and competitive action on behalf of the viewer. The image of the tortured slave in sympathetic fantasy creates a perverse comparative ground in which the audience is "vying to see who can suffer more, the victim in her tortured state, or the sympathetic voyeur in his ability to think himself into her pain" (131). The rhetorical competition imbedded in the sympathetic viewing of the image of the tortured slave also creates a form of possession and exertion over the slave body that disturbingly mimics the dynamics of slavery-the viewer can "can come back to and 'enjoy' the suffering of the fantasy slave at any time, and in any way he likes. This act of imaginative possession exists in troubled relation to the manner in which a real slave owner can use the slave's body at any time, in any way" (16). The commodification and objectification of the image of the punished slave body via sympathetic framing, the competition and possession imbedded in sympathetic fantasy, suggests that these images "are not about black slave lives and black slave suffering, but about white fantasies of black slave lives and black slave suffering" (21). As a result, Wood's analysis radically interrogates a reading of images of slave suffering as resistant to histories of romanticization, instead framing them as their own form of romanticization and erasure.

Wood's interrogation of the rhetorical objectification, commodification, and fetishization of the image of the tortured slave body is echoed in several reviews of McQueen's 12 Years a Slave. In a review titled "Where are the Serious Movies About Non-Suffering Black People?", author 
Roxanne Gay argues that Hollywood has a particular fetish for depicting the torture and subjugation of the enslaved black body, and that this fetish, rather than depicting the reality of slavery, often works to specifically limit and erase representation. According to Gay, "Hollywood has very specific notions about how they want to see black people on the silver screen .... .all too often, critical acclaim for black films is built upon the alter of black suffering or subjugation." Here, echoing Wood, Gay identifies the ways in which the tortured black body is fetishized and romanticized through sympathetic consumption, as well as how the cultural investment in these images controls and contains narratives of black experience and life. In this way, Gay engages in a larger discourse interrogating the rhetorical performance of images of the tortured slave body, ultimately reading the ways in which these images implicitly engage and reaffirm the structures of power they claim to challenge and subvert.

The ambiguity of McQueen's images of slavery, particularly the image of the tortured slave body, is reflected in the ambiguity of discourse surrounding images of slavery in visual culture. This ambiguity is indicative of what Marcus Wood calls "the violent instability of the slavery archive," its seemingly endless capacity for appropriation and refraction (Slavery, Empathy and Pornography, 7). Wood, along with many trauma studies scholars, also questions to what degree the lived experience and transhistorical memory of slavery may be inaccessible and unreachable. For Wood, "the images reproduced mimic the experience... yet for each slave the experience was unrepeatable, irreducible, and irreproducible, all human suffering exists beyond the vulgarity of the simulacrum" (7). In this way, according to Wood, the images of slavery call us "to be witness to the unrepresentable."

In Remnants of Aushwitz: The Witness and the Archive, author Giorgio Agamben argues that testimony and bearing witness to atrocity occupies a particular hinge: "On the one hand, what happened .... appears to the survivors as the only true thing and, as such, absolutely unforgettable; on the other hand, this truth is to the same degree unimaginable, that is, irreducible to the real events that constitute it." (12). This hinge of the unimaginable and the incomprehensible, the unforgettable and the inarticulateable, is indicative of a "lacuna" specifically imbedded in the nature of testimony itself. However, the paradoxical ambiguity that makes up the lacuna of testimony is not something to be resolved; it is not through a process of resolving the lacuna of witnessing that one locates the nature of testimony. Rather, the author argues that the lacuna of witnessing points to the very structure of testimony; that inherent to and imbedded in the nature of testimony is the simultaneous impossibility of bearing witness.

This analysis of testimony has specific implications with regard to the instability and ambiguity of McQueen's images of the violence of slavery, the discourse on images of slavery in visual culture, and the very nature of representation itself. Rather than view the instability of images of slavery in McQueen's 12 Years a Slave, and within the larger body of visual culture, as something to be deciphered and resolved in order to locate the memory of slavery and its representation, it is possible that something like the memory of slavery lies in this paradox and inherent impossibility of "realism" itself. If the memory of slavery is irrecoverable, if trauma is defined by what is not there and cannot be represented, then perhaps imbedded within the paradox of the real, framed and defined always by what is not real and not there, is something close to the meaning and memory of slavery and its violence. 


\section{WORKs Cited}

Agamben, Giorgio. Remnants of Auschwitz: The Witness and the Archive. New York: Zone, 2002. Print.

Davis, Natalie Zemon. Slaves on Screen: Film and Historical Vision. Cambridge: Harvard University Press, 2000. Print.

Fryd, Vivien Green. "Bearing Witness to the Trauma of Slavery in Kara Walker's Videos: Testimony, Eight Possible Beginnings, and I was transported." Continuum: Journal of Media and Cultural Studies 24.1 (2010): 145-159. Print.

Gay, Roxanne. "Where Are the Serious Movies About Non-Suffering Black People?”. Vulture. 6 Nov. 2013. Web, 9 Sept. 2014.

James, Kendra. “The Racialicious Review of 12 Years a Slave." Racialicious. 21 Oct. 2013. Web. 9 Sept. 2014.

Wood, Marcus. Blind Memory: Visual Representations of Slavery in England and America 17801865. Manchester: Manchester University Press, 2000. Print.

Wood, Marcus. Slavery, Empathy and Pornography. New York: Oxford University Press, 2002. Print. 


\title{
On Cinematography and Discomfort in 12 Years a Slave
}

\author{
-Kathryn Hampshire
}

Slavery is violent by its very nature. From the physical brutality to the psychological damage enslavement inflicts, a discussion of violence is vital for any conversation surrounding the subject of this institution. In 12 Years a Slave, the director, cinematographer, and actors present viewers with a disturbing and uncomfortable final product in what cultural historian Dr. Thomas Doherty says "has already been called the most searing depiction of slavery ever projected on the American screen" (5). By lingering on scenes a bit longer (sometimes a lot longer) and providing stark contrasts that highlight the horrors of the narrative, the film forces audience members to confront their own discomfort about the subject head on.

"[R]elentless cinematic intensity" is prevalent from the very beginning when the camera pushes its way through leaves in the field "closing in like vegetative shackles he [Solomon] cannot hack away" (Doherty 5). This scene creates a claustrophobic feeling which sets viewers up for the discomfort to follow. Several times, director Steve McQueen utilizes his actors' faces to further the themes of distress and pain. According to scholar Deborah E. McDowell, "In giving so much visual and sonic space to the mournful and melancholic-forlorn looks, grieving eyes, audible sobs-McQueen allows us to consider slavery's devastating hold on the emotional lives of the enslaved" (379), a concept which I find most evident in a scene toward the end of the film.

This nearly silent (minus a storm brewing in the distance) extended shot of Solomon's angst-ridden face includes a full 14 seconds of direct eye contact. This scene has not received much attention thus far, but I propose that it is one of the most powerful in the film. According to director of photography and camera operator Sean Bobbitt in an interview with TIME LightBox, this is exactly what he was going for in what he attests is his favorite scene: "His face isn't moving, and yet we see the whole of his life written in his eyes, the compassion and the horror and the dignity all welled up inside him," he said, "and then he does that little glance into the camera, it was like a physical blow to the chest. It's so simple and powerful, and for me that's what cinematography should be" (qtd. in Moakley). Extended eye contact can be uncomfortable enough in person since, as Dr. Gwyneth Doherty-Sneddon points out, "Looking at faces is quite mentally demanding [especially] when we are trying to concentrate and process something else that's mentally demanding" (qtd. in BBC). From a film with so much difficult material for viewers to process already, these moments are all the more disconcerting. Solomon forces the audience to acknowledge his tortured, hollow eyes, empty yet full of pain — so telling of slavery's inherent nature-in such an uncomfortable, unsanitized, and unashamed way as to show slavery for what it is.

Two scenes in particular receive the most attention within critical conversations about the film: the hanging of Northup and the whipping of Patsey. The incredible violence and inhumanity depicted in these moments certainly render them memorable, but the more subtle aspects of the cinematography are what truly make them stand out from the rest of the film.

With the hanging scene, Bobbitt was not about to let the audience off easy. In an interview with the Hollywood Reporter, he said, "Each of the [hanging scene] shots is held for a long period of time, specifically to make the audience as uncomfortable as possible and to force them to reflect on what was happening to Solomon and how terrifying that must have been" 
(qtd. in Giardina). Capping off at 1:26 of uncut footage, the film forces the audience to watch as Northup balances on his toes in the mud to prevent his suffocating in the noose. With little action on screen except for a few slaves going about their business in the background and hardly any noise but the sickly squishing of sludge beneath his toes, this scene is purposefully brutal to watch.

When the camera finally breaks from this angle, viewers get a moment of respite. The film's next two minutes of Northup's struggling to stay alive represent the hours he had to wait for his own relief (which, notably, must come at the hands of his master) by showing the daylight changing and other slaves going about their daily activities in the background. "What was very important is that the audience gets a sense of the passage of time, and sense the length of the shots, that feeling of the duration of the day," said Bobbitt (qtd. in Moakley). It is important here to reference how this theme of relief without resolution continues through to the end of the film when Solomon is finally rescued from slavery. In that moment, though relieved for his salvation, the audience also experiences unfulfilled yearning for a happy ending to Patsey's story too as she only fades further into the background, a lingering message of slavery's still unresolved legacy in both history and modern times alike.

The suffering Solomon faces in his hanging contrasts with the anguish he is forced to inflict on a fellow slave in the other highly-discussed scene: Patsey's whipping. Continuous shooting was important to the crew to depict this extreme inhumanity. Bobbitt said to the Hollywood Reporter:

$[\mathrm{T}]$ hat was always going to be one continuous shot.... The audience is given no relief. Once you put a cut in, then subconsciously everyone is aware that they are watching a film, and it lets them off the hook .... Particularly for a scene like that, with the complexity of the emotions and the violence going on, it really acts to heighten the drama and the performance of the actors. (qtd. in Giardina)

In this continuous shot totaling a whopping 6:21, the camera includes "multiple perspectives of victim, perpetrator, unwilling participant, and enthusiastic onlooker" (Doherty 7). This observation is certainly important; thus, I wish to delve further into its implications. The cinematography avoids jump cuts between perspectives since these leaps tend to give viewers the sense of "jumping" into individual characters' heads for certain moments of a narrative. Instead, the film opts for an omniscient, authentic, and continuous shot which shows the events and the various people involved blatantly as they are.

One significant element of this scene has gone generally unnoticed, but I wish to draw attention to it here. It is only after following the soap-the small, pure, innocent cause of so much violence, wretchedness, and suffering - fall gently to the ground from Patsey's hands that the camera finally breaks. But, instead of offering a moment of relief to the audience, it does the opposite: the screen goes straight to a shocking shot of Patsey's lacerated back, "the most extreme and horrid of the many images of bodily harm in 12 Years a Slave" (Doherty 7). By doing so, I propose that the film demonstrates how even something_or someone_innocent, clean of any stain of guilt, can be twisted and warped through the violence of slavery.

The break between the scenes also shows how, in the life of a slave, there are no moments of relief; even when one expects a reprieve, she may only face further suffering. By imposing this feeling of hopelessness and apprehension on the audience, these scenes force viewers to experience and confront their discomfort with the violence of slavery. By making the audience uncomfortable instead of opting for a more sanitized version of the story, this film draws attention to the twisted nature of slavery through these unrelenting depictions of depravity. 
In addition to these scenes of violence, I would also like to emphasize how this film's cinematography provides stark contrasts which make the audience view these events in a different light than they may have without these contrasts. First, we will examine Solomon's transition from loving to loathing his one source of solace-his violin. At 6:30, viewers receive close-up footage of him taking care of his beloved instrument, which directly contrasts a scene nearly two hours later when he destroys one. The camera zooms in on the violin like the previous scene, only now depicting pain instead of care. Whereas in the beginning Solomon carefully tunes his instrument, now he tightens each string until it snaps, then breaks the neck in half. I find the fact that the latter of the two scenes follows Patsey's whipping to be significant: it shows how this act has forced him over the edge to the point where something which once brought him solace is now symbolic of suffering.

Several times, setting itself provides contrast. Toward the beginning, the camera focuses on patriotic symbols. When Solomon is beaten and held in a cell, the camera pans from the barred window up to a picturesque view of the Capitol Building and other easily-recognizable D.C. landmarks. Harvard professor John Stauffer points out how, later in the film, one can see the Washington Monument through a spinning paddle-wheel of the ship taking Solomon south which "zooms toward us, filling the screen, suggesting the closed society in which it heads" (318). In addition to his observation, I would like to elaborate by saying that these juxtapositions of the institution of slavery with contemporary symbols of patriotism serve an additional purpose: they force the audience to the uncomfortable acknowledgement of the horrors in the country's history and their reverberations into the present.

Setting the rest of the film in Louisiana gave the crew the opportunity to present visuals as "an ironic compensation during all the human misery" since "all would be beautiful were not the impenetrable landscape a natural penitentiary” (Doherty 7 ). I find a prime example of Doherty's point at 33:00, when the camera shows silhouettes of nature and then pans to a line-up of slaves. Later, when Solomon is whipping the overseer Tibeats, the wide camera angle shows the violence of the act juxtaposed with the calm of the scenery.

In my critical analysis, I also observe how the use of dark versus light conveys disparity by allowing viewers to experience despair along with Solomon. When he first finds himself a captive, the scene sharply breaks from the brightness of his last meal as a free man to the pitch blackness of his cell. His flashbacks to the night before are increasingly darker as they progress, symbolizing his descent into a living hell. At the night's close, the men blow out a candle as they also blow the life and hope from his existence for the 12 years to follow. Later, when a fellow laborer betrays Solomon's trust, light from a lantern goes away, leaving him in the pitch black with only his despair. He throws his letter into the fire, and viewers watch as the embers slowly fade away, creating a growing sense of hopelessness as Solomon's hope dies along with them.

Cinematographic temporality also aids in this depiction of contrasts while also contributing to our discussion of discomfort. By using combinations of long takes and close-ups, Bobbitt creates a sense of "slow-as-molasses meteorology" (Doherty 7). Even when the camera does move unencumbered, the freedom it depicts is contrary to the subjects it captures. According to Doherty, in order “[ $t$ ]o evoke Solomon's stranded and locked-up condition, McQueen keeps his camera horizontal and close to the ground, taking his time to look straight at a vista or a face, with a minimum of non-diegetic music" (7). Indeed, along with emphasizing Solomon's lack of freedom, the film also demonstrates how his relativity in regards to time is completely dependent on his master. According to McDowell, "At every level of 12 Years a Slave, McQueen 
meditates on time and measures progress in painfully incremental steps and stages.... For Solomon, as for the viewer, time passes all too slowly" (376). Whether it be progress on Solomon's difficult road to freedom or his daily labors at the hands of his abusers, the painstakingly slow pace forces viewers to look at suffering far longer than they would wish.

Through these cinematographic strategies of temporality and disparity, we can come to a further appreciation for what this film accomplishes in terms of its depiction of slavery. Along with adding emphasis to their respective moments, these techniques also aid in the overall depiction of this brutal institution's violent nature. 12 Years a Slave presents audiences with such difficult viewing material that is free of sanitization. By doing so, it puts the audience members in a situation where they must either turn their eyes from the violence before them (as we so often do) or face that brutality and what it means that we are so disconcerted by it. However much we might want slavery to be the straightforward, sanitized problem of the past that so many films make it out to be, 12 Years a Slave forces us to face the fact that this peculiar institution still has reverberations into the present. 


\section{Works Cited}

12 Years a Slave. Dir. Steve McQueen. Perf. Chiwetel Ejiofor, Michael Kenneth Williams, Michael Fassbender, and Adepero Oduye. Regency Enterprises, 2013. Film.

BBC. “Pupils 'Must Look Away to Think.” BBC News. 11 January 2006. Web. 20 November 2014.

Doherty, Thomas. “Bringing the Slave Narrative to Screen: Steve McQueen and John Ridley's Searing Depiction of America's 'Peculiar Institution.” Cineaste: America's Leading Magazine on the Art and Politics of the Cinema 39.1 (2013): 4-8.

Giardina, Carolyn. "'12 Years a Slave' Cinematographer Sean Bobbitt: Not Letting the Audience Off the Hook.” The Hollywood Reporter. 17 October 2013. Web. 14 September 2014.

McDowell, Debora E. “How Long?-Not Long.” American Literature History 26.2 (2014): 374-384.

Moakley, Paul. "Behind the Moving Image: The Cinematography of 12 Years a Slave." TIME LightBox, 27 February 2014. Web. 14 September 2014.

Stauffer, John. “12 Years between Life and Death.” American Literature History 26.2 (2014): 317-325. 


\section{Scoured Souls: The Imbalance between Mistresses and Female Slaves}

\section{-Ramona Simmons}

In examining slavery, the focus on the cycle of abuse tends to remain on the interaction between female slaves and their male masters. Any relationships existing between the mistress and female slaves were often overlooked, or downplayed as being friendly or even familial. As shown in popular slavery films like Django Unchained, and even mildly in 12 Years a Slave, female slaves were often depicted as being workers within the home who fulfilled many of the roles a traditional homemaker would, from cooking to cleaning. In contrast, because the domestic tasks were well-taken care of, mistresses developed relationships with these slave women in a quasi-friendly nature, as displayed in works like Gone with the Wind. In the duration of the Margaret Mitchel novel-based film, the bond between Scarlett O'Hara and Mammy is portrayed as more of a maternal disposition where the slave acted as a nanny for a young woman until she grew older. 12 Years a Slave shatters this serene portrait by deploying characters such as Mistress Epps and Patsey, showing the darker side of the mistress-female slave interactions as being one of hatred and jealousy. To fully understand this shift in presentation of women in slavery, it is important to understand the false mutual oppression of both women in slavery. Often, it seems that both sets of women were subjected to dominance by the slave master, leading to both groups being viewed as victims. Although this is true, we less often examine how this can lead to the mistress's abuse of the female slave to empower herself. Lastly, it is equally important to expose the clash between the women's roles in slavery that transformed into a relation of violence from a mistress towards a slave.

Upon looking at slavery witnessed in 12 Years a Slave, it could be argued that mistresses and female slaves were found in the same predicament in their oppression within patriarchy. Master Epps belittles Patsey, a female slave that is highlighted as his favorite for the amount of work she can accomplish in comparison to the other slaves. This earns her the title of "Queen of the Fields," which in turn captures the plantation mistress' attention. Outraged by the energy Master Epps places in praising and eyeing Patsey, Mistress Epps demands for her husband to end his improved attitude towards and treatment of Patsey. Master Epps refuses, for he thinks of himself as the ruler of the entire plantation, his wife unequal to his status, and blatantly ignores her requests, leaving the audience a glimpse of how mistresses were oppressed by their husbands.

Although the mistress was ranked higher in the social hierarchy, both the mistress and the female slave answered to the male master of the land. Mistresses were viewed as psychological slaves to their husbands through their lack of equality in status. Within her essay Charlotte Arbogast goes into the shared "property" state of both women saying, "The confines of gender for white women in southern society also meant that upon getting married, white women turned into a form of 'property' for their new husbands" (Arbogast 1). This reality was showcased in several ways that dominated a mistress' typical life. She was expected to serve as a child bearer, maiden of the household, devout Christian, and entertainer, everything that comprised the picture of domesticity. Typically, the slaves belonged to the master. As a result, oftentimes there would be a power struggle between a mistress and her husband, as any orders from the husband would override requests by the mistress. An imbalance in slave control between mas- 
ter and mistress could thereby be attributed to the gender-specific roles within the community in which slavery occurred. Buhle, Murphy, and Gerhard, American historians and professors at assorted U.S. universities, explain the lack of feminine power due to her domination in the private circles (i.e. household function concerns), whereas her husband was within the public circles (associated with politics and economy) ( $\mathrm{xx}$ ). With his role being the financial provider, this introduces another layer of complexity of reliance that the slaves and mistress both had concerning the master. Without the men to supply money and conduct business, the mistress and slaves were thought to be lost, as the mistress held little social standing; meanwhile the slave held none at all. For example, both women and slaves did not have a voice within politics to interject their own opinions for change, which speaks to the mistress' near-nonexistence and the slaves' nonexistence in the realm of politics. Mistresses themselves were still involved in social networks more so than slaves, as they did have certain rights and were active in engagements with other society members, which were key rights that slaves were deprived of.

When considering the mistreatment of female slaves at the hands of their mistresses, the physical harm is what comes to mind primarily. Even women who did not own slaves themselves sought out slaves as the gateway for them to achieve true housewife status. Within his study, Soul by Soul: Life Inside the Antebellum Slave Market, Harvard University professor William Johnson develops the idea that if a mistress was to have house slaves, they would clear her of having to perform the physical labor of being a housewife. She would still be credited as being responsible for a successful domestic life without having to endure the physical labors of doing so, fulfilling her time leisurely with her family and hosting acquaintances (79-162). The abuse of power over house slaves was something that seduced many mistresses and led to violence as a possible coercion tactic to encourage obedience.

Despite domination being necessary in order to secure social status, others have shined a light on the emotion aspects of producing such violence. Conflict would arise in that "many incidents involving the cruelty of a mistress also involved a female slave's alleged intimacy with the master" (Reilly 52). Arguably, the free women who committed these infractions against slaves felt threatened by slaves who were supposed to be of a lower social standing than them. The mistresses' real anger stemmed directly from the very system in which they found themselves. Michaela Davis discusses the challenge to their position that the mistresses felt and the inability they had to confront their husbands about the white male supremacy that prevented them from advancing on in the hierarchy (Davis). Thereafter, the mistresses would oppress any slaves that had relations (unwanted or not) with her husband in order to deprive him of one avenue of pleasure he sought out (Davis).

Within the movie, the compliance of Mistress Epps with the slave system is appalling and one that makes the audience root against her. Her use of violence towards Patsey was a theme throughout the movie that was sickening, a derivative of the grotesque animalistic advances of Master Epps on Patsey. As Patsey improves throughout her time at the Epps' plantation, this awards her the attention of Master Epps. While he takes a greater notice of her, Mistress Epps is in the wings, watching exactly how far Master Epps will take his taboo relationship with Patsey. Soon enough, Mistress Epps notices that Master Epps finds attraction in the qualities she does not possess herself, such as extreme physical labor productivity.

A particular scene that draws attention to the attraction Master Epps carelessly displays is one in which he wakes all of the slaves up in the dead of night to make them dance within his home. Solomon plays the violin while his fellow slaves follow suit after an intoxicated Master 
Epps and his chosen partner, Patsey. During this parade of lunacy on behalf of Master Epps, Mistress Epps enters the scene to investigate what it is the slaves are performing. This is when her eyes are set on Patsey, with whom Master Epps has taken the liberty to dance. Upon doing so, she disrupts them and comes face-to-face with Patsey. She finds herself torn because she has been beaten out socially by an individual who is supposed to be inferior to her status. Once she realizes this, she confronts Patsey by shattering a glass and raking it down her face. Screaming in agony, a confused Patsey has blood rush profusely from her face and is taken away to be cared for.

The scene illustrated above refers to many reasons why white slave women were active participants in the cruelty against their slaves. If it did not scare obedience into the slave, the purpose was then to find a way to disrupt any relationship between the slave (Patsey) and master (Master Epps). Collectively as females, both sets of women were subjected to mental abuse from a typically controlling and overbearing white male master, admittedly. Despite this similarity in circumstance, female slaves emerged as the individuals suffering the most abuse, becoming sexual objects for masters to prey upon. Alongside, they became victims of the mistress' violence for these unwanted sexual advances from the master. Although the Scarlett O'Hara's and Mammy's of the film industry would have consumers think otherwise, there was a much darker side to the relationship between the two women who held the master's attention, unwanted (by the slave) or yearned for (by the mistress). This dimension of the mistress-female slave relationship is a side often kept within the darkness of the same shadows that conceal the painful truth of being a female of color in the Confederate South. 


\section{Works Cited}

Arbogast, Charlotte E. “Perceptions of White Mistresses: The 'Mistress' and the 'Dear White Mother.” Lynchburg College. Web. 14 Sept. 2014.

Buhle, Mari Jo, Teresa Murphy, and Jane Gerhard. Women and the Making of America. Upper Saddle River: Pearson, 2008. Print.

Davis, Michaela Angela. "12 Years a Slave: Rage, Privilege, Black Women and White Women." Jezebel. Gawker Media. 28 Oct. 2013. Web. 14 Sept. 2014.

Johnson, William. Soul by Soul: Life Inside the Antebellum Slave Market. Cambridge: Harvard University Press, 1990. Print.

Reilly, Elizabeth Lauren. The "Scab" of Slavery: Interracial Female Solidarity in Literature About the Antebellum South. M.A. Thesis. Vanderbilt University, 2008. Print.

White, Deborah Gray. Ar'n' I a Woman?: Female Slaves in the Plantation South. New York: W. W. Norton \& Company, 1999. Print. 


\title{
The Inability to Commit Suicide: An Analysis of Steve McQueen's 12 Years a Slave
}

\author{
- Bryce Longenberger
}

Suicide is destructive in its very nature. The act of suicide ends the life of a person, which is accomplished intentionally and purposefully by the hand of that very individual. It is not shocking that a system such as slavery, which is inherently violent and degrading in nature, would drive a person to desire and succeed in taking his or her own life. In this essay, I will explore the way in which Steve McQueen utilizes the idea of suicide in his film 12 Years a Slave to highlight the extent to which slavery can degrade a human being and shape his or her life into a zombie-like state of existence. And it is at this point where he or she does not even possess the capability of taking his or her own life.

Before I examine the role of suicide and slavery in the film itself, I want to outline the history and theories behind suicide and slavery throughout history. The scholarship on this intersection has been scarce throughout the decades since slavery's end. Terry L. Snyder indicates that the nature of self-destruction among slaves has been largely overlooked because, during the time of slavery, it was difficult to determine the number of slaves who committed suicide versus slaves who died of other causes (40). However, some research does exist, and Snyder states that the research that has been done concludes that slaves who committed suicide often acted in defiance of and in resistance to their masters.

One of the earliest pieces of research on suicide as a form of resistance appeared in the 1940 's when Raymond and Alice Bauer described the various ways in which slaves resisted their masters, including feigning illness and inflicting pain upon themselves. They noted, however, that in extreme cases, slaves would commit suicide as "an indirect means of retaliation" (418). Although this research is over half a century old, this view has not subsided in recent years. Snyder also states in her 2010 article that "slave suicide often has been rightly perceived as a form of defiance" and that it can indeed be seen as "the ultimate form of resistance" that a slave can perform (42). Suicide here allowed a slave to resist his circumstances and ultimately the master who enslaved him. Surprisingly enough, suicide serves a dual purpose beyond mere resistance. Linda Kay Kneeland explains that slaves would choose suicide as a form of retaliation when they "determined that they were unwilling to exist under the only choices they could perceive, and when they saw only more pain in their future" (9). It seems that despair and surrender were incredibly significant in a slave's decision to end his or her own life. And so, suicide in slavery has been seen to be both a form of resistance to the master's authority and an act of escape and release from the pain the slave has endured.

As we now move our attention to an analysis of the film, I would first like to describe the ways in which suicide appears in both Solomon's narrative and the film. In Solomon's narrative, he dwelt on the thought of suicide in multiple places in his novel. The prospect of death was always on his mind, and he was constantly thinking that "death was far less terrible than the living prospect that was before" him (Northup 40). But even more striking than his obsession with death are his thoughts of regret and jealousy for not being dead himself. In his narrative, after Robert is killed on the steamboat heading south to Louisiana, Solomon muses, "There was a feeling of utter desolation in my heart, filling it with a despairing and regretful sense, that 
I had not gone down with Robert to the bottom of the sea" (Northup 44). Solomon clearly believed at times in his enslavement that it would be much better, even beneficial, for him to end his life and be done with all of the violence and suffering that life as a slave had to offer him.

For the most part, the theme of suicide is mirrored in McQueen's film version of 12 Years a Slave. The most prominent parallel between the book and the film appears again during the ride on the steamboat to Louisiana. The day after Robert is killed while trying to resist a white man who is taking Eliza away in the night, Solomon and another black man are disposing of Robert's body. After they dump his body overboard, Solomon stares at the body floating away and appears to be mourning the loss of Robert's life. But Solomon's companion breaks the silence, turning to Solomon and saying, "[He's] better off; better than us." Even though Solomon never expresses suicidal thoughts in the film, here again we see this idea that death is preferable to life. Even though they do not mention suicide, the act hangs as a constant possibility and a chance to join the dead man who is "better off" than the living slave.

The second appearance of suicide in the film is actually a major deviation from Solomon's narrative, and it is on this deviation that our analysis of the film will rest. This is the scene where Patsey asks Solomon to kill her. In Solomon's narrative, we see that Patsey never expresses an interest in ending her life. She may have thought about it on countless occasions, but she never expresses the actual desire to end her life, at least according to Solomon. In the film, however, McQueen chose to have Patsey attempt to kill herself even though she never actually follows through. Toward the end of the film, before Patsey is brutally whipped, Patsey approaches Solomon in the dead of night and asks Solomon the following in a pleading voice with great conviction and determination: "All I ask: end my life. Take my body to the margin of the swamp ... take me by the throat, hold me low in the water until I am still and without life." Solomon immediately becomes appalled by the fact that Patsey has fallen into such despair. When he pleads with her, she claims passionately, "I ain't got no comfort in this life." When Solomon still resists her pleas, she begs with him, asking him to "do what I ain't got the strength to do myself” (McQueen).

Overall, scholars have discussed the issue of suicide in the film quite extensively, just not the reasons why Patsey was unable to end her own life. John Stauffer discusses the film through the framework of survivalism, which he argues plays a huge role in slaves' lives, until the point where they "perceive living in slavery as worse than death, and it is at this point that they rebel” (319). As we've already seen, this rebellion often occurs in the form of suicide. But scholars also stress the fact that this rebellion is still fueled by a desire for release from this life. In analyzing the importance of Patsey in the film and her role in gaining narrative authority, Salamishah Tillet concludes in her paper that the experiences of "Solomon's fellow slaves are so abject" that they believe "death, by suicide or murder, might be [a] viable alternative" (359). What Tillet and Stauffer are suggesting is the inescapable fact that slaves who commit suicide are reacting to the "abject" circumstances of their lives by choosing to both rebel against their master and release themselves from their miserable lives. As we can clearly see, this matches the research done on suicide and slavery throughout history.

Even though scholars have discussed why slaves might want to commit suicide, they have not touched on the reason why Patsey does not commit suicide. If Patsey had committed suicide, it would indeed have allowed her to resist the "rape by her master" and the "odium of Mistress Epps" (Stauffer 320). By committing suicide, she would have been able to resist her master and release herself from a life full of violence. But Patsey does not do this. We must 
then ask two major questions: why does Patsey not commit suicide, and why does McQueen add the scene where Patsey expresses a desire to commit suicide when it was not even mentioned in Solomon's narrative? To answer these questions, I believe that McQueen represents Patsey as having endured so much pain in her life that she has resigned herself to merely surviving instead of living. In this zombie-like state, I believe that Patsey is incapable of taking her life with her own two hands. I also believe McQueen added this scene not to comment on what suicide allows a slave to do but rather to comment on a system of oppression that is so degrading that it can cause a person to fall into such a wretched state of existence based solely on surviving instead of living.

The idea of survivalism is introduced in John Stauffer's article where he defines the life of a slave as existing in a "state of war" between life and death itself, which results from the "extreme power imbalance between master and slave" (317). He focuses his attention on Solomon Northup; he states that Solomon is forcibly kept alive so that he may labor for his master, but then he is simultaneously subjected to extreme violence and brutality that threatens him with death. In this way, Stauffer argues that Solomon, and slaves in general, constantly dangle between life and death, touching both at the same time yet never staying on a definitive side. Because of this, many slaves resort to merely surviving instead of living or dying. In the film, when Solomon is whisked away to be enslaved in the south, a fellow slave tells him that he must be quiet about his identity in order to survive. Solomon retorts in disbelief and rage, saying, "I don't want to survive; I want to live." But after Solomon has been subjected to the demoralizing violence of slavery, Eliza asks Solomon how he can bear the loss of his children so well. Solomon screams back at her in desperation: "I survive!" Solomon has been exposed to such extreme forms of violence and degradation that he is no longer fully able or willing to live or die; he has instead been forced to resign himself to a structuralized state of survival and mere existence. We can see here that the oppression slaves are subjected to renders them into a system that places them into a structure that resembles that of mindless zombies, people who are neither truly dead nor alive but merely existing and unable to change the circumstances of their own lives.

In the film, Patsey's life is very much centered on survivalism - between death and truly being alive-as well. When Master Epps discovers that she left the plantation for a bar of soap, Patsey cries, "I stink so much I make myself gag ... and for that I will be clean. That is all I ask" (McQueen). This desire to be clean, to merely cease the stench that is emanating from her body, is clearly a desire grounded in a person who is merely trying to survive life, to get through a single day at a time. We also see the ways in which Patsey is unable to help herself. After her brutal beating towards the end of the film, her lacerated back is being cleaned, and she looks up at Solomon and a tear slides down her face (McQueen). She is silently asking Solomon why he did not end her life; she is asking him why he did not do what she did not have the power or strength to do herself. Because Patsey has been subjected to more violence and brutality than any human being can conceivably live through, she is enduring the violence because she can do nothing to stop it herself.

The fact still remains that McQueen could have had Patsey end her own life; it would have been a deviation from the book and would have altered the effect of the film dramatically. If McQueen had wanted to comment on the atrocities of slavery by having Patsey actually end her life, he could have done so. Instead, McQueen chose to insert this instance of not being able to commit suicide. I believe McQueen intentionally included a scene where Patsey expresses a desire to commit suicide because he wanted to introduce the idea of a system of 
oppression that alters the human condition in a way where suicide becomes impossible. By including this scene, McQueen stresses the dehumanization of slaves like Patsey who have been rendered into zombies who can merely exist and survive.

At the end of the film, Solomon is taken back to his family in the North. He has been given back his life and can live out the remainder of his life with his family away from the constant presence of the whip. But as the carriage carrying Solomon from Epps's plantation continues moving toward us on the screen, the background becomes fuzzy, and we see Patsey fall to the ground in a miserable heap. In this hazy backdrop, which blurs not only the scenery but Patsey herself, McQueen reminds us once again of the extremity of violence that is inherent in slavery. As the movie ends, we cannot forget Patsey and her zombie-like state. Despite Solomon's relatively happy ending, Patsey will always haunt us and remind us of the degrading essence of slavery and its power to make some humans into beings that can merely exist, beings who may desire to live or die but are nevertheless powerless to change their fate either way. 


\section{WORKs Cited}

Bauer, Raymond A. and Alice H. Bauer. "Day to Day Resistance to Slavery." The Journal of Negro History 27.4 (1942): 388-419. JSTOR. Web. 23 September 2014.

Kneeland, Linda Kay. "African American Suffering and Suicide Under Slavery.” MA thesis. Montana State University, 2006. Web. 22 September 2014.

McQueen, Steve, dir. 12 Years a Slave. Regency Enterprises, 2013. Film.

Northup, Solomon. Twelve Years a Slave. 1853. Ed. Henry Louis Gates, Jr. New York: Penguin, 2012. Print.

Snyder, Terry L. "Suicide, Slavery and Memory in North America." Journal of American History 97.1 (2010): 39-62. Web. 23 September 2014.

Stauffer, John. “12 Years between Life and Death.” American Literary History 26.2 (2014): 317 325. Project Muse. Web. 8 September 2014.

Tillet, Salamishah. "I Got No Comfort in This Life': The Increasing Importance of Patsey in 12 Years a Slave." American Literary History 26.2 (2014): 354-361. Project Muse. Web. 8 September 2014. 